\title{
Cyanide Degradation by Pseudomonas pseudoalcaligenes Strain W2 Isolated from Mining Effluent
}

(Penguraian Sianida oleh Pseudomonas pseudoalcaligenes Strain W2

Dipencilkan daripada Sisa Air Lombong)

\section{BELINDA TIONG, ZARATULNUR MOHD BAHARI, NOR SAHSLIN IRWAN SHAH LEE, JAFARIAH JAAFAR,} ZAHARAH IBRAHIM \& SHAFINAZ SHAHIR*

\begin{abstract}
Cyanide is highly toxic to the living organisms as it inhibits respiration system in the cell mitochondria. Cyanide is commonly used in gold extraction process and its discharge into the environment not only causes pollution but it also brings harm to the surrounding population. Chemical treatment is expensive and the use of hazardous compound can exacerbate the problem. Biodegradation offers cheap and safe alternative as it overcomes the problems faced by chemical treatment. In this study, indigenous bacteria from mining wastewater were isolated. Cyanide degradation was done via shake flask method. A bacterium, designated W2 was found able to grow in the mining wastewater. 16S rRNA analysis identified the strain as Pseudomonas pseudoalcaligenes which could tolerate up to $39 \mathrm{mg} / \mathrm{L}$ cyanide concentration and growth was depleted at $52 \mathrm{mg} / \mathrm{L} .60 \%$ cyanide degradation was achieved in wastewater containing medium. End-product analysis from high performance liquid chromatography (HPLC) detected formamide implicating the role of cyanide hydratase in cyanide degradation. It can be concluded that P. pseudoalcaligenes is capable of biodegrading cyanide and its potential in wastewater treatment containing cyanide is feasible.
\end{abstract}

Keywords: Biodegradation; bioremediation; cyanide; mining wastewater; Pseudomonas pseudoalcaligenes

\section{ABSTRAK}

Sianida adalah sangat toksik kepada organisma hidup, kerana ia menghalang sistem respirasi dalam sel mitokondria. Sianida biasanya digunakan dalam proses pengekstrakan emas dan pembebasannya ke alam sekitar bukan sahaja menyebabkan pencemaran tetapi ia juga membawa kemudaratan kepada populasi sekitar. Rawatan kimia adalah mahal dan penggunaan sebatian yang berbahaya memburukkan lagi masalah sedia ada. Biopenguraian menawarkan alternatif yang murah dan selamat, oleh itu ia mengatasi masalah yang dihadapi oleh rawatan kimia. Dalam kajian ini, bakteria asli daripada air sisa perlombongan berjaya dipencilkan. Analisis penguraian sianida telah dilakukan melalui kaedah goncangan kelalang. Sejenis bakteria, dinamakan W2 didapati mampu tumbuh di dalam air sisa perlombongan. Analisis 16S rRNA mengenal pasti bakteria tersebut sebagai Pseudomonas pseudoalcaligenes dan ia boleh bertoleransi sehingga $39 \mathrm{mg} / \mathrm{L}$ kepekatan sianida dan pertumbuhan telah berkurangan pada kepekatan sebanyak $52 \mathrm{mg} / \mathrm{L}$. $60 \%$ penguraian telah dicapai di dalam medium yang mengandungi air sisa. Analisis produk-akhir daripada kromatografi cecair prestasi tinggi (HPLC) telah mengesan formamida yang mengaitkan peranan sianida hidratas dalam penguraian sianida. Dapat disimpulkan bahawa Pseudomonas pseudoalcaligenes yang dipencilkan berupaya menguraikan sianida dan potensi dalam rawatan air sisa mengandungi sianida boleh dilaksanakan.

Kata kunci: Air sisa lombong; biopemulihan; biopenguraian; Pseudomonas pseudoalcaligenes; sianida

\section{INTRODUCTION}

Cyanide is an extremely toxic compound to living organisms as it acts as a metabolic inhibitor which forms very stable complexes with transition metals that are essential for protein function (Luque-Almagro et al. 2005). Toxicity of cyanide and the awareness on its toxicity have caused continuous research being carried out to reduce or eliminate the concentration level of cyanide in cyanide containing wastewater. Chemical treatments for cyanide include alkaline chlorination, $\mathrm{SO}_{2} /$ AIR (INCO) process and copper-catalyzed hydrogen peroxide (Akcil 2003). However, these methods lead to high consumption of chemicals and formation of toxic intermediates which were complex to handle and high in cost.

Biodegradation of cyanide by bacteria is an attractive alternative that offers more efficient, eco-friendly and cost effective. Bacteria and fungi have been identified as the sources of biological degradation for cyanide (Dash et al. 2008). Different organisms utilize different enzymatic pathways to degrade cyanide into less toxic compounds such as ammonia, carbon dioxide, formic acid or formamide (Gupta et al. 2010). Several microorganisms have been found useful for degrading 
cyanide: Burkholderia cepacia strain C-3 utilized cyanide as the nitrogen source for growth (Adjei \& Ohta 2000) and produced ammonia $\left(\mathrm{NH}_{3}\right)$ and carbon dioxide $\left(\mathrm{CO}_{2}\right)$ meanwhile Klebsiella oxytoca is capable of biodegrading cyanide into ammonia and methane (Kao et al. 2003).

Further works on isolation of various microorganisms with the capability to degrade cyanide will provide a better platform to maximize the potential of cyanide biodegradation. A recent research utilized strains of Rhodococcus isolated from cyanogenic plants in Peninsular Malaysia for bioremediation of cyanide (Maniyam et al. 2011). The strain could metabolize up to $312 \mathrm{mg} / \mathrm{L}$ cyanide. Due to the recalcitrance of cyanide and its related compounds to biodegradation, the present study was undertaken to further screen for cyanide-degrading microorganisms from cyanide contaminated mining wastewater in Malaysia. This article reports the isolation, physiological characterization and cyanide degradation potential of Pseudomonas pseudoalcaligenes strain W2.

\section{MATERIALS AND METHODS}

\section{ISOLATION AND IDENTIFICATION OF CYANIDE DEGRADING BACTERIA}

Gold mine in Kuala Lipis, Pahang was chosen as the site for microorganism isolation. Cyanide is used at the mine to extract gold from gold-bearing ores thus making the environment a potential site for isolating cyanide resistant degrading bacteria. Water sample were collected from the tailing dam. The wastewater medium $(90 \%(\mathrm{v} / \mathrm{v})$ of filtered-sterilized wastewater and $10 \%(\mathrm{v} / \mathrm{v})$ nutrient broth) was used for isolation of the bacteria while mineral salt medium (MSM) was used for cyanide degradation study. The mineral salt medium contained $0.0057 \mathrm{M}$ of $\mathrm{K}_{2} \mathrm{HPO}_{4}$, $0.025 \mathrm{M}$ of $\mathrm{KH}_{2} \mathrm{PO}_{4}, 0.0077 \mathrm{M}$ of $\mathrm{NaCl}, 0.00671 \mathrm{M}$ of $\mathrm{KCl}$, $0.5 \mathrm{mM}$ of $\mathrm{MgSO}_{4} \cdot 7 \mathrm{H}_{2} \mathrm{O}$ and $0.03 \mathrm{mM}$ of $\mathrm{FeSO}_{4} .7 \mathrm{H}_{2} 0$. The medium was amended with $0.5 \mathrm{mM}$ of $\mathrm{MgSO}_{4} \cdot 7 \mathrm{H}_{2} \mathrm{O}$, $0.03 \mathrm{mM}$ of $\mathrm{FeSO}_{4} .7 \mathrm{H}_{2} 0,10 \%(\mathrm{v} / \mathrm{v})$ and trace element ( $\mathrm{Na}_{2}$ EDTA:5g, ZnO:0.05g, $\mathrm{CuCl}_{2} \cdot 2 \mathrm{H}_{2} \mathrm{O}: 0.01 \mathrm{~g},\left(\mathrm{NH}_{4}\right)_{6} \mathrm{Mo}_{7}$ $\left.\mathrm{O}_{24} .4 \mathrm{H}_{2} \mathrm{O}: 0.01 \mathrm{~g}, \mathrm{FeCl}_{3} 6 \mathrm{H}_{2} \mathrm{O}: 0.05 \mathrm{~g}\right)$. The final $\mathrm{pH}$ of the medium was adjusted to $\mathrm{pH} 10$ using $10 \mathrm{mM} \mathrm{NaOH}$ to avoid volatilization of free cyanide at a lower $\mathrm{pH}$. A mixture of samples from different sampling points was transferred into wastewater medium containing $260 \mathrm{mg} / \mathrm{L}$ cyanide which was then incubated at $30^{\circ} \mathrm{C}, 200 \mathrm{rpm}$. The culture was transferred onto the wastewater agar plate and incubated overnight at $30^{\circ} \mathrm{C}$. Each of different bacteria colonies was re-streaked onto the new plate till pure colonies were isolated. Identification was performed by 16S rDNA analysis. Genomic DNA was extracted by using DNA Extraction kit (GF-1) from Vivantis. 16S rRNA gene was amplified by PCR using universal primers (FP; 5'-AGAGTT-TGA-TCC-TGG-CTC-AG-3' and RP; 5'-GGT-TAC-CTT-GTTACG-AC-T-3') and the amplicons, purified, sequenced and analysed.

\section{SCREENING OF TOLERANCE LEVEL TOWARDS CYANIDE}

Resistance of strain for cyanide was determined by growing in WMSM medium (50\% wastewater, $50 \%$ mineral salt medium and $10 \mathrm{mM}$ sodium acetate) amended with increasing cyanide concentrations $(2.6,26,39$ and 52 $\mathrm{mg} / \mathrm{L}$ ). The sample without inoculums was set up as control. All the samples were incubated overnight at $30^{\circ} \mathrm{C}$ at $200 \mathrm{rpm}$. The growth of the cells was evaluated by measuring the absorbance at $600 \mathrm{~nm}$ after $12 \mathrm{~h}$ of incubation.

\section{BIODEGRADATION OF CYANIDE VIA BATCH STUDY}

Bacteria inoculum $(10 \% \mathrm{v} / \mathrm{v})$ was inoculated into a total volume of $100 \mathrm{~mL}$ of WMSM supplemented with $2.6 \mathrm{mg} / \mathrm{L}$ cyanide. The flasks were incubated at $30^{\circ} \mathrm{C}$, $200 \mathrm{rpm}$ for $24 \mathrm{~h}$. Control flasks without cells were incubated to check for abiotic transformation of cyanide. Sampling was done at regular time intervals throughout the growth of the culture for analysis of several different parameters related to the biodegradation which include optical density of the growth culture, $\mathrm{pH}$, cell dry weight, cyanide and ammonia concentration. Cell dry weight was analyzed as per method described by Chen et al. (2008). Cyanide concentration was determined by using PyridinePyralazone method (Epstein 1947) with detection limit of $0.008 \mathrm{mg} / \mathrm{L}$ whereas ammonia concentration was determined using Nessler method (Epstein 1947) with detection limit of $0.02 \mathrm{mg} / \mathrm{L}$.

\section{CYANIDE DEGRADING ENZYME ACTIVITY}

Inoculum was grown in a $500 \mathrm{~mL}$ solution comprised of $50 \%$ wastewater and $50 \%$ MSM with $2.6 \mathrm{mg} / \mathrm{L}$ cyanide at $\mathrm{pH} 10$. The culture was left in the shaker incubator at $30^{\circ} \mathrm{C}, 200 \mathrm{rpm}$. Cells were harvested at the exponential phase $(\mathrm{t}=18 \mathrm{~h})$ by centrifugation at $4000 \mathrm{rpm}$ for $20 \mathrm{~min}$. The cells were then suspended in $50 \mathrm{mM}$ Glycine- $\mathrm{NaOH}$ buffer (pH10) with twice the volume of the obtained pellet. The suspended cells were disrupted in a sonicator at $5 \%$ amplitude for $3 \mathrm{~min}$ at $4^{\circ} \mathrm{C}$. Disrupted cells were then subjected to centrifugation at $4000 \mathrm{rpm}$ for $45 \mathrm{~min}$ at $4^{\circ} \mathrm{C}$. Supernatant was kept to check for enyzme localization (Babu et al. 1996).

\section{DETECTION OF END-PRODUCT FOR BIODEGRADATION}

End product of the biodegradation was assayed using high performance liquid chromatography (HPLC) equipped with a $250 \times 4.6 \mathrm{~mm}$ C- 18 column (LiChroCART, purospher STAR RP-18). Mobile phase consists of double distilled water with the $\mathrm{pH}$ adjusted to $\mathrm{pH} 2$ with diluted $\mathrm{H}_{2} \mathrm{SO}_{4}(0.5 \mathrm{M})$. The sample was run through Waters $600 \mathrm{E}$ and UV detection was via Waters 2487 photodiode array detector. Elution was isocratic at flow rate of 0.5 $\mathrm{mL} / \mathrm{min}$ at $22^{\circ} \mathrm{C}$. All HPLC solutions were filtered and degassed before use. Absorbance value was read at the wavelength of $210 \mathrm{~nm}$. 


\section{RESULTS AND DISCUSSION}

\section{ISOLATION AND IDENTIFICATION OF STRAIN W2}

Three different colonies isolated named $\mathrm{W} 1, \mathrm{~W} 2$ and $\mathrm{Y}$ showed significant growth in the presence of cyanide. The pure isolates were grown separately in wastewater with mineral salt medium. The medium for bacterial growth was subsequently changed from wastewater containing $10 \%$ nutrient broth (NB) to mineral salts medium (MSM) due to the fact that nutrient broth (NB) will react with cyanide and cause the Killiani reaction. In this reaction, any aldehydes and ketones in the medium will react with the cyanide present, thus interfering with the biodegradation process (Luque-Almagro et al. 2005). Mineral salts medium will eliminate this possibility since it is a minimal growth media without any organic compound. W2 was selected for further study as it showed better and more stable growth in the presence of cyanide. Strain W2 was found to be a gram-negative, rod-shaped bacterium and was classified as Pseudomonas psuedoalcaligenes via 16 S rRNA sequence analysis. Figure 1 shows the constructed phylogenetic tree with strain W2 clustered within genus Pseudomonas. Pseudomonas pseudoalcaligenes CECT5344 has been reported earlier in the research by Luque-Almagro et al. (2005) for cyanide degradation under alkaline $\mathrm{pH}$ and added with acetate as the $\mathrm{C}$ source. Subsequent research by Luque-Almagro's group showed that this strain is able to produce siderophores which have the ability to break down cyano-metal complexes.

\section{SCREENING TOLERANCE LEVEL TOWARDS CYANIDE}

$P$. pseudoalcaligenes $\mathrm{W} 2$ was screened for its tolerance towards increasing concentrations of cyanide over a specified time interval via shake flask technique. The results are displayed in Figure 2. Cyanide concentration above $2.6 \mathrm{mg} / \mathrm{L}$ induced a longer lag phase, a result which Kao et al. (2003) has also reported. T-test were done using the values obtained at $\mathrm{t}=30 \mathrm{th} \mathrm{h}$. It was determined that there was no significant difference between growth at concentration above $13 \mathrm{mg} / \mathrm{L}$ cyanide. The growth of P. pseudoalcaligenes W2 was inhibited at a higher concentration of cyanide. Different bacteria strains were found to have different tolerance to cyanide concentration. For example, a study by Chapatwala et al. (1998) on Pseudomonas putida showed that growth was the highest at $4 \mathrm{mM}$ cyanide and was inhibited at $8 \mathrm{mM}$. In another study, Burkholderia cepacia strain C-3 could tolerate up $10 \mathrm{mM}$ of cyanide (Adjei \& Ohta 2000).

\section{BIODEGRADATION OF CYANIDE}

As shown in Figure 3, there was a significant drop of cyanide concentration in the sample with inoculum added as compared to that of control sample without inoculum. The control set did not show obvious loss of cyanide which suggests the decrease in cyanide level was related to the biological activity of the isolated strain. Percentage of cyanide degraded was the highest at the late stationary phase $(18 \mathrm{~h})$. Degradation of higher cyanide concentrations by other bacteria has been observed. For instance, Klebsiella oxytoca grown in nitrogen free glucose medium (NFG) supplemented with glucose $(0.8 \% \mathrm{w} / \mathrm{v})$ was capable of degrading more than $92 \%$ of cyanide from initial concentration of $0.58 \mathrm{mM}$ (Kao et al. 2003). In liquid minimal medium supplemented with fructose $(1 \% \mathrm{w} / \mathrm{v})$, Burkholderia cepacia strain C-3 was found to be able to degrade $10 \mathrm{mM}$ of potassium cyanide (KCN) (Adjei \& Ohta 2000). Addition of glucose and fructose to the medium could provide a reason for higher cyanide concentration degraded by respective bacterium, in contrast with strain W2 in this study that only had minimal carbon source.

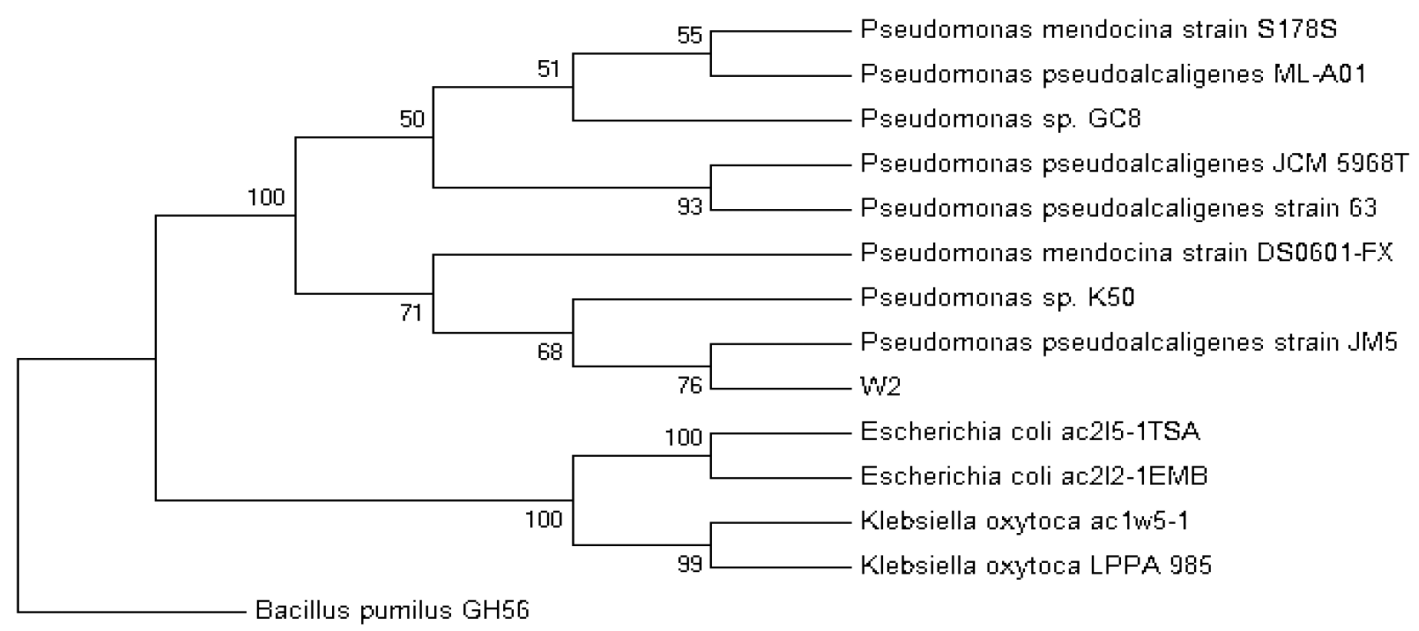

FIGURE 1. Phylogenetic position of strain W2 based on 16S rRNA sequence. Numbers at each point of the branch are the bootstrap values 


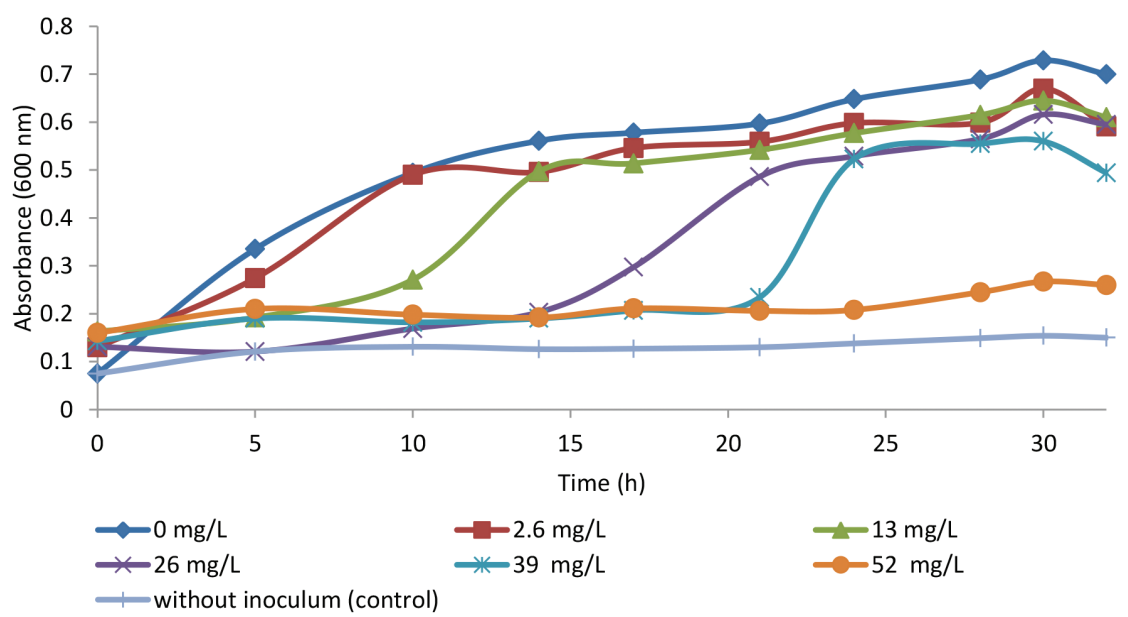

FIGURE 2. Growth of Pseudomonas pseudoalcaligenes strain W2 in different cyanide concentrations at $30^{\circ} \mathrm{C}, 200 \mathrm{rpm}$. The values are means of triplicates

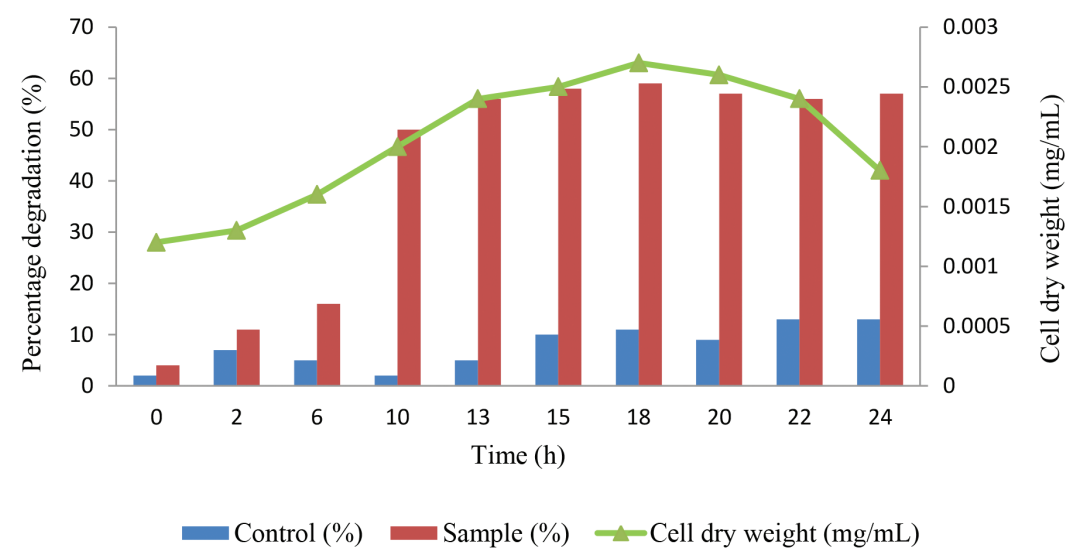

FIGURE 3. Percentage of cyanide degraded in growth medium with final concentration of $2.6 \mathrm{mg} / \mathrm{L}$ cyanide. Cell dry weight $(\mathrm{mg} / \mathrm{mL})$ was taken during the period of cyanide degradation

\section{AMMONIA CONCENTRATION}

Microbes can break down cyanides into ammonia (Harris \& Knowles 1983). However, different microorganisms utilize different pathways to achieve this. The breakdown of cyanides into ammonia involves hydrolysis via an enzymatic reaction. As seen in Figure 4, a significant decrease in the concentration of ammonia was observed at the $2 \mathrm{nd}$ till the $13 \mathrm{th} \mathrm{h}$. $\mathrm{pH}$ of the medium also remained at an alkaline $\mathrm{pH}$ thus preventing volatilization of poisonous HCN gas. The decrease in ammonia concentration as the result of increase cyanide degradation was a most interesting observation. The most plausible explanation for this is that the medium used was a nutrient limiting medium; hence ammonia produced was rapidly used by growing microorganisms as nitrogen source. This is supported by similar finding from the study by Kao et al. (2003) with the strain Klebsiella oxytoca grown in NFG medium precultivated with $0.5 \mathrm{mM}$ of cyanide. Ammonia was produced by the resting cells of Klebsiella oxytoca during cyanide degradation in phosphate buffer but not in growing cells due to lower assimilation rate of ammonia. These findings suggested that an enzymatic mechanism through hydrolytic pathway was involved in the conversion of cyanide to ammonia.

\section{CYANIDE DEGRADING ENZYME ACTIVITY}

Cyanide degrading enzyme activity was assessed in the cell free extract of strain W2. Cells grown in the presence of mineral salts medium (MSM) with wastewater containing $2.67 \mathrm{mg} / \mathrm{L}$ cyanide were harvested at the end of the stationary phase. As shown in Figure 5, ammonia was being released consistently as cyanide was gradually being depleted due to the enzyme activity. This shows that cyanide-degrading enzyme activity was present in the cell free extract of strain W2. Enzyme activity was calculated based on the ammonia produced. For each mole of cyanide degraded, one mole of ammonia was released (Babu et al. 1996). The activity of the enzyme in crude cell-free 


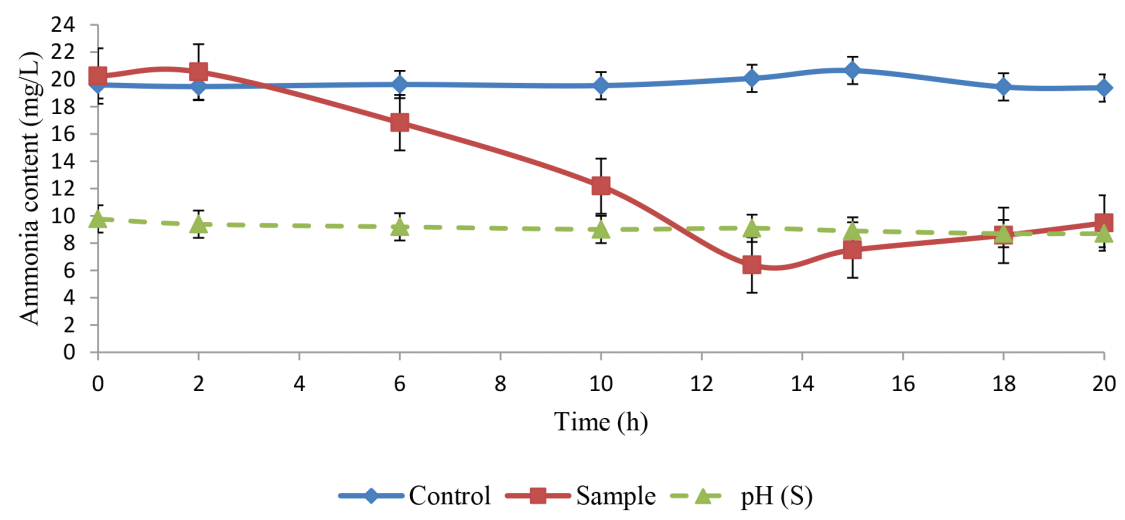

FIGURE 4. Ammonia content during biodegradation of cyanide by Pseudomonas pseudoalcaligenes in 50\% wastewater and $50 \%$ mineral salt medium at initial $\mathrm{pH} 10$. The values are means of triplicates

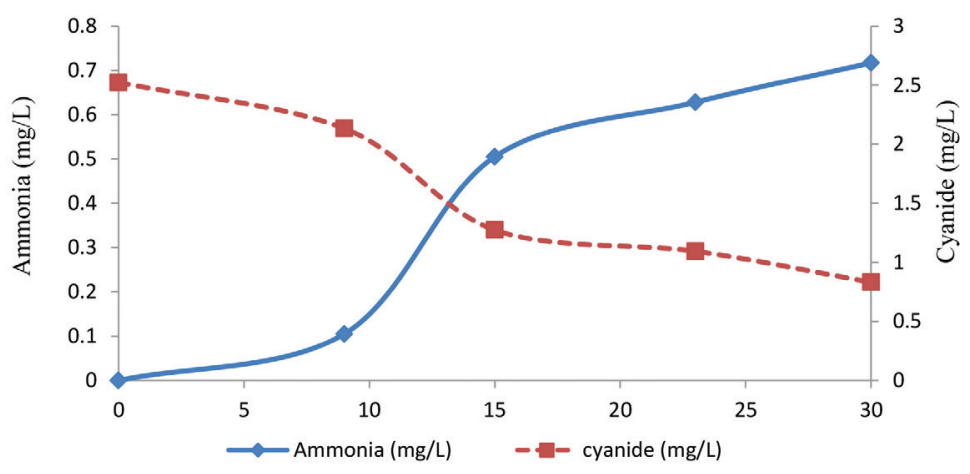

FIGURE 5. Degradation of cyanide by cell free extract in the mineral salt medium (MSM) with wastewater containing $2.6 \mathrm{mg} / \mathrm{L}$ cyanide

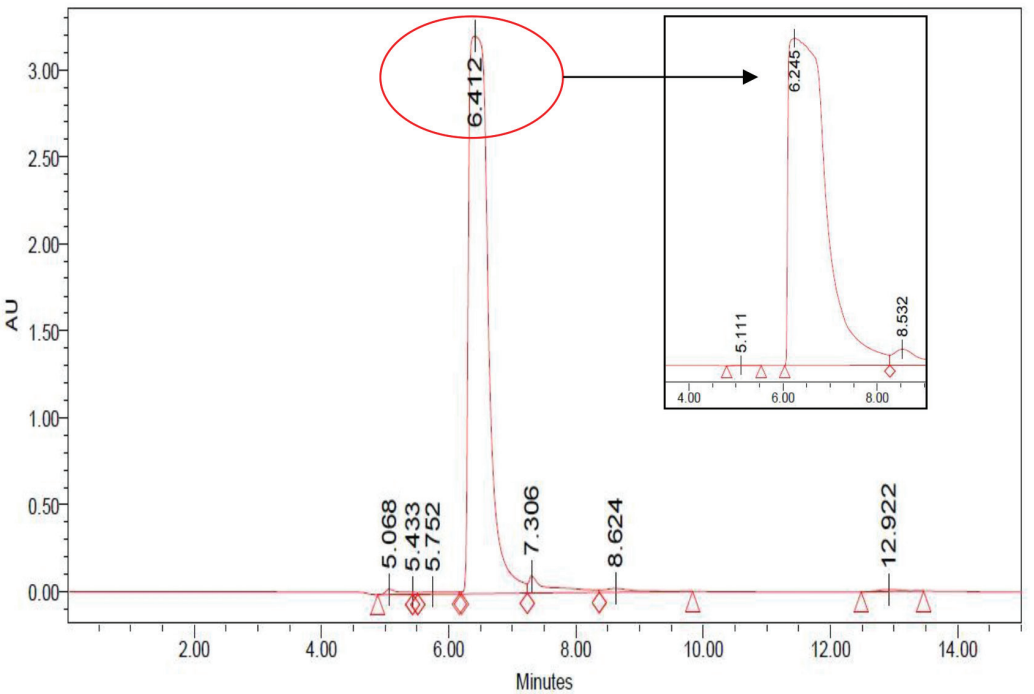

FIGURE 6. Detection of cyanide biodegradation end product after $24 \mathrm{~h}$ with high performance liquid chromatography (HPLC) which corresponds to formamide standard (inserted graph)

extract was found to be $11.4 \mathrm{mg} / \mathrm{L}$ ammonia produced $/ \mathrm{mL} /$ $\mathrm{min} / \mathrm{mg}$ protein. Harris and Knowles (1983) reported that Pseudomonas fluorescens NCIMB 11764 converted cyanide into both ammonia and carbon dioxide from the cell free extract. Moreover, Kunz et al. (1994) reported similar finding whereby enzyme cyanide hydratase was found to 
be responsible for cyanide-degrading activity in the cellfree extract from Pseudomonas fluorescens NCIMB 11764. It was reported that two possible end products formed as a result of cyanide degradation are formate and formamide (Kao et al. 2003).

\section{END PRODUCT DETERMINATION}

From the HPLC analysis (Figure 6), one peak was detected with the retention time of $6.412 \mathrm{~min}$. This peak was then identified to correspond to the peak of formamide. Cyanide hydratase has been reported to catalyse the conversion of cyanide to formamide (Dubey \& Holmes 1995). Hence, this result indicated that cyanide hydratase was responsible for degrading cyanide in strain W2. More interestingly this enzyme is commonly found in algae. For example, in Fusarium solani, hydrolysis occurs and forms formamide by action of cyanide hydratase (Barclay et al. 1998). Cyanide hydratase is also present in several other fungi such as Gloeocercospora sorghi and Fusarium lateritium (Barclay et al. 1998).

\section{CONCLUSION}

A strain of cyanide-degrading bacteria identified as $P$. pseudoalcaligenes strain W2 was successfully isolated from mining wastewater. End-product formation of formamide suggested that enzyme cyanide hydratase was present. $\mathrm{pH}$ of the medium was maintained at alkaline condition which plays a crucial factor in biodegradation of cyanide as acidic condition will easily cause formation of poisonous $\mathrm{HCN}\left(\mathrm{pK}_{\mathrm{a}}=9.2\right)$. Cyanide degrading activity by the crude cell-extract was recorded to be at $11.4 \mathrm{mg} / \mathrm{L}$ ammonia produced $/ \mathrm{mL} / \mathrm{min} / \mathrm{mg}$ protein. The present outcome of this study suggests that the isolated $P$. pseudoalcaligenes strain W2 could potentially be used for bioremediation of cyanide contaminated wastewater.

\section{ACKNOWLEDGEMENTS}

We thank the Ministry of Education (MOE), Malaysia for the financial support (FRGS Vot No 78414) and Universiti Teknologi Malaysia for the research facilities. The authors also would like to thank Specific Resources Sdn Bhd for providing the mining effluents.

\section{REFERENCES}

Adjei, M.D. \& Ohta, Y. 2000. Factors affecting the biodegradation of cyanide by Burkholderia cepacia strain C-3. J. Biosci. Bioeng. 89: 274-277.

Akcil, A. 2003. Destruction of cyanide in gold mill effluents: Biological versus chemical treatments. Biotechnol. Adv. 21: 501-511.

Babu, G.R.V., Vijaya, O.K., Ross, V.L., Wolfram, J.H. \& Chapatwala, K.D. 1996. Cell-free extract (s) of Pseudomonas putida catalyzes the conversion of cyanides, cyanates, thiocyanates, formamide, and cyanide-containing mine waters into ammonia. Appl. Microbiol. Biotechnol. 45: 273-277.
Barclay, M., Hart, A., Knowles, C.J., Meeussen, J.C.L. \& Tett, V.A. 1998. Biodegradation of metal cyanides by mixed and pure cultures of fungi. Enzym. Microb. Tech. 22: 223-231.

Chapatwala, K.D., Babu, G.R.V., Vijaya, O.K., Kumar, K.P. \& Wolfram, J.H. 1998. Biodegradation of cyanides, cyanates and thiocyanates to ammonia and carbon dioxide by immobilized cells of Pseudomonas putida.J. Ind. Microbiol. Biotechnol. 20: 28-33.

Chen, C.Y., Kao, C.M. \& Chen, S.C. 2008. Application of Klebsiella oxytoca immobilized cells on the treatment of cyanide wastewater. Chemosphere 71: 133-139.

Dash, R.R., Gaur, A. \& Balomajumder, C. 2008. Cyanide in industrial wastewater and its removal: A review on biotreatment. J. Hazard. Mater. 163: 1-11.

Dubey, S.K. \& Holmes, D.S. 1995. Biological cyanide destruction mediated by microorganisms. World J.Microbiol. Biotechnol. 11: 257-265.

Epstein, J. 1947. DR 2800 Spectrophotometer Procedures Manual-Hach. Anal. Chem. 19: 272.

Gupta, N., Balomajumder, C. \& Agarwal, V.K. 2010. Enzymatic mechanism and biochemistry for cyanide degradation: A review. J. Hazard. Mater. 176: 1-13.

Harris, R. \& Knowles, C.J. 1983. Isolation and growth of a Pseudomonas species that utilizes cyanide as a source of nitrogen. J. Gen. Microbiol. 129: 1005-1011.

Kao, C.M., Liu, J.K., Lou, H.R., Lin, C.S. \& Chen, S.C. 2003. Biotransformation of cyanide to methane and ammonia by Klebsiella oxytoca. Chemosphere 50: 1055-1061.

Kunz, D.A., Wang, C.S. \& Chen, J.L. 1994. Alternative routes of enzymic cyanide metabolism in Pseudomonas fluorescens NCIMB 11764. Microbiology 140: 1705-1712.

Luque-Almagro, V.M., Huertas, M.J., Martinez-Luque, M., Moreno-Vivian, C., Roldan, M.D., Garcia-Gil, J., Castillo, F. \& Blasco, R. 2005. Bacterial degradation of cyanide and its metal complexes under alkaline conditions. Appl. Environ. Microbiol. 71: 940-947.

Maniyam, M.N., Sjahrir, F. \& Ibrahim, A.L. 2011. Bioremediation of cyanide by optimized resting cells of Rhodococcus strains isolated from Peninsular Malaysia. Int. J. Biosci. Biochem. Bioinformatics 1: 98-101.

Belinda Tiong, Zaratulnur Mohd Bahari, Nor Sahslin Irwan Shah Lee, Zaharah Ibrahim \& Shafinaz Shahir*

Department of Biosciences and Health Sciences

Faculty of Biosciences and Medical Engineering

Universiti Teknologi Malaysia

81310 Johor Darul Takzim

Malaysia

Jafariah Jaafar

Department of Chemistry, Faculty of Science

Universiti Teknologi Malaysia

81310 Johor Darul Takzim

Malaysia

*Corresponding author; email: shafinazshahir@utm.my

Received: 24 October 2013

Accepted: 25 July 2014 